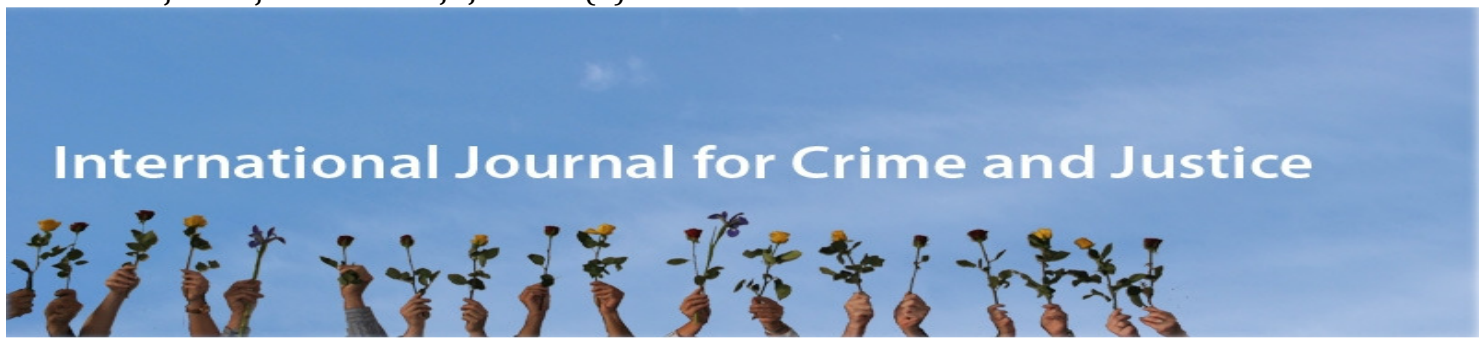

\title{
Resource Extraction Leaves Something Behind: Environmental Justice and Mining
}

\author{
Rob White
}

University of Tasmania, Australia

\begin{abstract}
Environmental justice is concerned with the health and wellbeing of individuals, groups and communities in regards to toxic environments. Within this framework, it has long been noted that oil, timber and minerals are extracted in ways that can devastate local ecosystems and destroy traditional cultures and livelihoods. Resource extraction is thus not socially and environmentally neutral but has a number of potential ramifications directly related to ecological wellbeing and human health. The aim of this paper is to explore the social injuries associated with the mining industry, especially as this pertains to vulnerable population groups. As the title indicates, a key concern is what resource extraction leaves behind and how this impacts upon local areas now and into the future.
\end{abstract}

\section{Key Words}

Mining, environmental justice, resource extraction, environmental harm.

\section{Introduction}

Resource extraction industries are the economic lifeblood of countries such as Australia. Mining, forestry and petroleum (involving drilling at sea as well as on land) constitute major sources of revenue and profit for states and corporations alike. They employ many people, across a broad range of occupations and types of paid work. They also demand huge expenditures from the point of view of investment, exploration, operations and rehabilitation. Resource extraction is not cheap. It also has its environmental and social costs.

Indeed, resource extraction is not socially and environmentally neutral but has a number of potential ramifications directly related to ecological wellbeing and human health. The creation of 'ghost towns' after the departure of mining companies is an enduring image and legacy of the industry. More recent and highly publicised social impacts are associated with the employment of fly in/fly out (and drive in/drive out) crews, which are affecting both previously stable mining communities and residential communities far from actual mining operations 
(Carrington, Hogg and McIntosh 2011; Carrington, McIntosh and Scott 2010; Cleary 2012). The harms resulting from extractive industries like mining are and should be an issue of major public concern (Carrington et al. 2011; Munro 2012). These include harms stemming from environmental degradation and contamination.

The impetus for this article was allegations of 'dirty business' in the upper Hunter Valley of New South Wales, initially signalled by the rise in illnesses such as asthma and cancers among local people (Fowler 2010; see also Munro 2012). Visits to the region by journalists uncovered regular incidences of toxic gas in the form of a yellowy orange cloud (that is, nitrous oxide), the origins of which were linked to local mines and especially the large open cut mines. More generally, yearly statistics show a total of 108 tonnes of toxic metals, including arsenic, cadmium, cobalt and lead, being poured into the air of the Upper Hunter from mines and power stations, along with 122,000 tonnes of sulphur dioxide (Fowler 2010). Not surprisingly, there have been calls for an independent inquiry, comparative health research, and identification of the content and danger levels for each substance. However, there have also been allegations of state-corporate collusion in dealing with the issue and, in particular, that the Department of Environment knows about the problem, but is not formally acting upon it (Fowler 2010).

In some circumstances, mining ventures create toxic sites and thus produce the conditions for contaminated communities, with significant detrimental consequences for local habitats and human residents. The negative impact of the mining industry on the environment is well known and readily acknowledged, not only by conservation bodies and environmental activists but also by governments and the mining industry itself (see Australian Bureau of Statistics 2003; ANZ Minerals and Energy Council and Minerals Council of Australia 2000; Lacey, Parsons and Moffat 2012; Thomson and Joyce 2006). Indeed, public pressure has ensured that recent years have seen considerable industry attention being paid to improving standards of environmental management and ensuring the rehabilitation of mined-out areas.

Nonetheless, significant questions remain about the environmental and social consequences of mining, particularly the huge large-scale open-cut mining projects currently in operation in Western Australia, New South Wales and Queensland, and new forms of mining such as coalseam fracking in the Eastern States. The aim of this paper is to explore issues of harm from the point of view of environmental justice, which is concerned with the disproportionate harmful effects of industrial production on particular individuals and groups. As the title indicates, a key concern is what resource extraction leaves behind as mining occurs (namely, toxic materials and air pollutants) and how this impacts upon local areas now and into the future.

\section{Environmental justice}

Environmental justice (concerned with humans) constitutes one strand of an eco-justice perspective that also includes ecological justice (concerned with nature and specific environments) and species justice (concerned primarily with nonhuman animals) (White 2013). It refers to the equitable distribution of environments among peoples in terms of access to and use of specific natural resources in defined geographical areas, and the impacts of particular social practices and environmental hazards on specific populations (as defined on the basis of class, occupation, gender, age, tribe, caste and ethnicity). It is especially concerned with the health and wellbeing of individuals, groups and communities in regards to toxic environments (Bullard 2005a, 2005b; Pellow 2007).

The emergence of environmental justice movements stems from actual experiences and events that negatively affect individuals and their communities. The impetus is experiential and concrete. For 'green criminology' as an academic field in enquiry, study of environmental justice involves engaging in a critical criminology that is informed by considerations of social and 
ecological justice. In essence, the focus of research and analysis is on investigation of social differences and inequalities in relation to the environment/society nexus.

As extensive work on specific incidents and patterns of victimisation demonstrates, some people are more likely to be disadvantaged by environmental problems than others. This is evident with respect to the location of toxic waste dumps, extreme air pollution, chemical accidents, access to safe clean drinking water and so on (see Chunn et al. 2002; Saha and Mohai 2005; Williams 1996). It is the poor and disadvantaged who suffer disproportionately from such environmental inequalities, whether this is in the United States (Bullard 1994), Canada (Rush 2002), India (Engel and Martin 2006) or Australia (Walker 2006). Moreover, it is these communities that also suffer most from the extraction of natural resources. For example, in many places around the globe where minority or Indigenous peoples live, oil, timber and minerals are extracted in ways that devastate local ecosystems and destroy traditional cultures and livelihoods (Brook 2000; Gedicks 2005; Schlosberg 2007).

The environmental justice framework seeks to prevent environmental threats and is premised upon a series of interlinked propositions and principles (see Bullard 2005b). These principles emphasise values such as social equity (in which all individuals should have a right to be protected from environmental degradation) and harm prevention (that focuses on eliminating a threat before harm occurs). Each of these areas requires that considerable resources be devoted to measuring things such as human exposure to environmental chemicals, and sociological analysis of harm and risk distributions among diverse population groups.

An important part of the environmental justice framework is ideological and practical support for the adoption of the precautionary principle. From a social movement perspective the preferred emphasis when it comes to precaution is to err on the side of human safety and wellbeing rather than industrial development. As Bullard (2005b: 28) observes:

It asks 'How little harm is possible?' rather than 'How much harm is allowable?' This principle demands that decision makers set goals for safe environments and examine all available alternatives for achieving the goals, and it places the burden of proof of safety on those who propose to use inherently dangerous and risky technologies.

Moreover, the environmental justice framework requires that those 'parties applying for operating permits for landfills, incinerators, smelters, refineries, chemical plants, and similar operations must prove that their operations are not harmful to human health, will not disproportionately affect racial and ethnic minorities and other protected groups, and are nondiscriminatory' (Bullard 2005b: 28-29). The mining industry is directly implicated in these kinds of assessments.

\section{Resource extraction, mining and environmental harm}

Resource extraction has a long history and extensive geographical reach. It is also tied to who has the power to do what, where, how cost effectively, and for whose benefit. It is vitally important to national economies and corporate profits, especially where overall gross domestic product is reliant upon these types of industries. It provides jobs and, depending upon where and how the workforce is housed, can provide significant economic multiplier benefits to towns and remote communities.

Australia currently has a booming resources sector:

Australia's thriving resources sector (comprising minerals and petroleum) is the country's largest single export sector. In 2006-2007 over 80 per cent of its output 
was exported, accounting for approximately 49 per cent of total goods and service exports. During that period, the minerals and petroleum industries produced over eight per cent of Australia's GDP and accounted for 63 per cent of Australia's merchandise export earnings. Australian coal, liquefied natural gas, iron ore, copper, diamonds, zinc and many other minerals provide the essential ingredients of growth for many nations. (Department of Foreign Affairs and Trade 2008)

Within the last few years, the revenue earned by mining companies has risen to now constitute a 15 per cent share of Australia's economy, and is still growing (Cleary 2012: xi). There are now 373 operating mines in Australia, and recent trends have been toward establishment of new operations and transformation of existing operations into mega-mines (Cleary 2012). In Western Australia, most of these mines in are in remote areas; in the Eastern states of New South Wales and Queensland, the mines are located close to or on prime farmland.

Simultaneously, agricultural land in Eastern Australia is being dotted by an increasing number of coal-seam gas wells, with major implications for people and environments. The industry has the potential to:

contaminate underground acquifers; produce billions of litres of unmanageable saline waste water that will yield millions of tonnes of salt and threaten farmland, river systems and wetlands; overlay an extensive network of access roads and pipelines; accelerate climate change by leaking methane gas into the atmosphere; trigger earthquakes; depress land values; and imposing a crippling cost across the economy by doubling or even tripling the price of domestic gas. (Cleary 2012: 23-24)

The continuing expansion of the resources sector in Australia and stockpiles of present and legacy wastes from these activities thus have significant implications for physical and social environments. As recently documented by Munro (2012), the pollution accompanying mining is a matter of growing concern among those who live and work in coal-mining areas, who are experiencing the shattering effects on community and health from industry practices such as 'fracking' and open-cut mining.

Detrimental environmental impacts associated with mining are intrinsic to mining itself. This being the case, the crucial question is basically how best to weigh up specific types of environmental harm in regards to economic and social benefit. In other words, mining inevitably involves a trade-off between ecological considerations and economic gain. There is nothing particularly profound about this; nor is this trade-off confined solely to mining. It also pertains to other extractive industries, such as forestry and fishing.

The operational aspects of mining (that is, methods and technologies used in extraction) and the net consequences of mining (that is, the overall impact on particular extraction sites) are the bread and butter of environmental impact assessment and the basis for the construction of a community 'social license to operate' (see Thomson and Boutilier 2011). In other words, short of banning mining altogether, the project of environmental justice (and ecological sustainability) is one of equity and ecological wellbeing, within the overarching framework of Nature-human interaction. The point is not necessarily to stop mining (although this may be warranted in some instances) but to ensure the least harm when doing it.

However, measuring harm and regulating it is complex in and of itself. Consider, for example, recent global efforts surrounding environmental regulation. Reforms in environmental management and regulation have also been closely linked to efforts by transnational corporations to further their hegemonic control over the planet's natural resources (Goldman 
1998a, 1998b). Markets may be protected through universalising environmental regulation (developed in and by the private sector, sometimes with NGO collusion, and later enforced by governments in the form of preferred contracts and business legal requirements) that themselves advantage the high-technology, well financed companies of the advanced industrialised countries (Goldman 1998a, 1998b). The largest companies are most likely to be capable of being environmentally 'virtuous' and thus to be granted rights and contracts related to natural resource extraction and use.

To see environmental regulation in this light is to acknowledge the economic rather than ecological rationale behind the actions of global regulatory bodies like the World Trade Organisation, International Monetary Fund and World Bank (see Friedrichs and Friedrichs 2002). Such 'regulation' is about facilitation of the exploitation of nature and humans, not about human interests and needs and ecological wellbeing as such. Enhanced 'environmentally friendly' production and extraction of natural resources do not change the status quo - such enhancements still collectively degrade the global ecological commons. The problem, here, is one of scale of the overall activity, which is given legitimacy by the technical regulation of specific activities.

The sheer scale of mining operations and how they are carried out is also highly relevant in considerations of the anthropocentric causes of climate change. Mining can have substantial impact in regard to greenhouse gas emissions. For example, the Alberta Tar Sands project in Canada is notorious for its huge contribution to greenhouse gas emissions because of the enormous size and the open-cut methods of the mining operations (Klare 2012). In Australia, recent legal action against extensions to existing open cut coal mining operations in Queensland have highlighted the environmental impact, including greenhouse gas emissions, resulting from such extensions (Millner and Ruddock 2011).

Importantly, the search for increasingly scarce natural resources is taking companies to new frontiers of mineral and gas exploration and technical exploitation. This carries with it several problematic risks. First, there are hazards and dangers associated with activities such as drilling in deep-offshore locations (as evidenced by the demise of the BP oil rig in the Gulf of Mexico); that is, new methods of extraction carry with them new dangers and new potential harms. Second, the more remote and marginal the areas that are exploited, and the more reliant on mining those communities become for their local economy, the less likely that there will be adequate regulation of mining activities. In either case, issues pertaining to extensive production of greenhouse gas emissions remain of general concern.

In addition to issues surrounding the contribution of mining to global warming (because of scale and method of operations, regardless of where they are located), there are other specific environmental issues that are associated with application of new methods of operation. For instance, in developed countries, there is presently much consternation and controversy over the environmental impact of 'fracking', a technique that involves using chemicals to extract coalseam gas. This issue is high on the public agenda in New South Wales and Queensland at the moment. In the United States, as with Australia, a major concern is that hydraulic fracturing fluids used to fracture rock formations contain numerous chemicals that can harm human health and the environment, especially if they enter drinking water supplies. A recent US report found that:

Between 2005 and 2009, the oil and gas service companies using hydraulic fracturing products contained 29 chemicals that are (1) known or possible human carcinogens, (2) regulated under the Safe Drinking Water Act for their risks to human health, or (3) listed as hazardous air pollutants under the Clean Air Act. (United States House of Representatives Committee on Energy and Commerce 2011: 1) 
It was also noted that, in many instances, the companies were injecting fluids containing chemicals that they themselves could not identify. Similar problems have been identified in Australia where public risk assessment of the chemicals being used is urgently needed (Cleary 2012). The main protagonists in the fracking debate within Australia are, on the one side, coal and gas companies and, on the other, farmers, tourism operators and environmentalists. Profit and power are the key determinants in these debates as is the extent of community mobilisation and politicisation of the issues. Consistent with the general pattern of environmental injustice, it is the most vulnerable who are likely to suffer from both take-over of land and radical alterations to existing land uses (Boekhout van Solinge 2008; Borras and Franco 2010).

\section{The social injuries of resource extraction}

Description and analysis of specific examples provide insight into the challenges to ecological and social wellbeing posed by the interface of mining and the environment. While not all mining companies and mining projects exhibit 'bad practice', there are ample numbers to illustrate the consequences when it does occur. Historical and social context is essential to understanding why such things happen.

Resource extraction is certainly not a new phenomenon. Indeed, the history of the modern world is based precisely upon resource extraction and conflicts over natural resources (Klare 2001). One aspect of these conflicts is seen in the processes of colonisation, a phenomenon that has affected many different Indigenous peoples in places such as South America, North America, and Australasia, as well as the native inhabitants of Africa, Asia and beyond (White 2011). In countries such as Australia, Indigenous territories were considered frontier lands that were unowned, under-utilised and therefore open to exploitation. The prior ownership rights, interests and knowledge of Indigenous inhabitants were treated as irrelevant by the European invaders. Environmental victimisation of this sort is central to dispossession and maltreatment of Indigenous peoples across many continents and over a period of several centuries.

Who is most negatively affected by resource colonisation is partly a function of what can be exploited, where it is located, and how much resistance is likely to be encountered. This is not just a thing of the past; it describes the present as well.

Multinational mining, oil, and logging corporations are now using advanced exploration technology, including remote sensing and satellite photography, to identify resources in the most isolated and previously inaccessible parts of the world's tropical rain forests, mountains, deserts, and frozen tundras. What the satellites don't reveal is the fact that native peoples occupy much of the land containing these resources. (Gedicks 2005: 168)

In a shrinking world, the search for 'green fields' for new development and for the exploitation of additional natural resources is intensifying and brings into play new technologies that facilitate ever greater extraction and processing of the Earth at a scale and pace never seen before. In the 'race for what's left', traditional and Indigenous people worldwide are especially vulnerable to the imposition of corporate power (Klare 2012). In Canada, for example, governments are eager to allow extraction industries to enter into and fully work lands occupied by Indigenous peoples, regardless of the wishes of the local people, and as particularly evidenced by the exploitation of the Alberta Tar Sands (Rush 2002; Smandych and Kueneman 2010).

\section{The livelihoods of traditional and Indigenous peoples}

Australian mining companies operating offshore have put profits before people in several notable instances. For example, over a period of many years, the BHP mine operators 
discharged 80 million tons of tailings, overburden and mine-induced erosion into the OK Tedi river system each year. This caused widespread harm to the 50,000 people who live in the 120 villages downstream of the mine. In the 1990s, the communities of the lower Fly Region sued BHP and received an out-of-court settlement, which was the culmination of an enormous publicrelations campaign against the company by environmental groups. In January 2007, another lawsuit was lodged on behalf of other villagers seeking billions of dollars in damage. The main beneficiaries from the mine have been BHP, the PNG government and the clan that holds ownership of the land on which the mine is built. Experts have predicted that it will take 300 years to clean up the toxic contamination (see Kirsch 2006; Low and Gleeson 1998).

In a similar vein, the negative social and environmental impacts caused by the operations of the Australian-owned Rapu Rapu polymetallic mine on Rapu Rapu island, the Philippines have been documented by Oxfam Australia (Martin and Newell 2008). Within the first six months of operation by the Lafayette Mining Limited mining company, poor environmental safeguards at the mine contributed to at least two cyanide-laden spillages and fish-kills. This has the additional knock-on effect of declining saleability of fish from the areas surrounding Rapu Rapu due to consumer fear of contamination. Concerns were consistently raised by members of neighbouring communities about the effects of the mine on health, potential detrimental impacts on the environment, and lack of benefits to local community members. The impacts of acid-mine drainage were of particular concern.

Land use that is dictated by the demands of mining companies is threatening the health and wellbeing of traditional owners. This is happening in Australia as well as overseas. In some cases this is regardless of claims that first-rate environmental regulation and management practices are in place. In the Northern Territory, for example, the Ranger uranium mine project has had devastating consequences for the local Mirarr people, but mining royalties and tax receipts seem to have a way of persuading authorities to ignore negative social impacts (Mudd 2008). What is at threat is not simply the immediate physical needs of Indigenous and traditional peoples but a whole way of life and livelihood that frequently includes hunting, fishing and small-scale agriculture. In the United States, for example, the Chippewa people have fought against mining operations on their lands, knowing that mining on their ceded lands would lead to environmental destruction of the land and water, thereby destroying their means of subsistence (Clark 2002; Schlosberg 2007). As with similar events elsewhere in the world, such contamination of the natural world constitutes an assault that goes to the heart of Indigenous culture and identity.

The mega-mining developments of contemporary Australia, however, are not only affecting particular Indigenous communities. Increasingly other types of poor or marginalised communities are also bearing the social and environmental costs of the resource extraction industries. This is especially evident when considering the farmers of the Hunter Valley (comprised of small family holdings through to wealthy landowners and pastoralists as well as wine-makers), or those living in towns and cities in Queensland subject to coal-seam gas drilling. The resource boom has the potential to produce grief for an increasingly wide spectrum of Australian society.

\section{The health of children}

Those who pursue environmental justice are particularly concerned with the most vulnerable sections of the human population, such as the elderly, the very young, people with disabilities and pregnant women. Yet, mining operations continue to put at risk the health of children living in places such as Queensland's Mount Isa. Mt Isa has two smelters that produce the largest source of lead emissions in Australia. Tests have revealed that the amount of lead in the blood of a third of the city's children who were tested breached World Health Organization acceptable limits, potentially affecting their IQ and brain development. The smelters release 290 tons of 
lead into the air in 2004-05, most of which, according to the company, were blown away by prevailing winds. Local residents have expressed grave concern about the state of health of their children and how the lead poisoning may affect them in future (Brockmann 2006; Queensland Health 2008).

Communities in Port Pirie, South Australia and Esperance, Western Australia, have also experienced disproportionately high levels of lead in blood tests taken on children. The Port Pirie lead smelter processes lead and zinc ore. Blood lead levels among children in Port Pirie have long been extraordinarily high. Even after an extensive Lead Implementation Program designed to use a variety of measures to reduce lead contamination and improve treatment, a plateau was reached where the blood lead levels are still excessive. Moreover, high lead blood levels still persist for about a quarter to a third of the children in the area (ABC News 2007; Harrison 2010; Muirden and Parnell 2003).

\section{The long-term wellbeing of local communities}

It is not only present mining operations that are associated with negative environmental and health impacts. Persistent pollution of surrounding areas can continue well after mining operations have ceased at the main site. For example, it has been noted that the recent floods in Queensland have exposed problems in many of the 15000 abandoned mines in that state, and the 50000 abandoned mines across the country (Townsend 2013). Abandoned mining lands refer to areas or sites of former mining activity for which no individual, company or organisation can be held responsible. These may be problematic at a number of different levels, and not only as evidenced in the transfer of waste water contaminants during exceptional (albeit regularly occurring) events such as floods or cyclones.

For example, the residents of Royal George, Tasmania source their drinking water from the nearby St Paul's River. Tests on the river found traces of aluminium, arsenic and other heavy metals, thought to be coming from the disused Brookstead mine. Water had to be trucked in to the north-east Tasmanian town because of concerns about safety of its drinking water (ABC News 2010a, 2010b). Meanwhile, as a result of over a century of mining at the Mt Lyell copper mine in Queenstown, Tasmania, large volumes of acid drainage carries with it tonnes of copper solution per day into the King and Queen Rivers systems. The consequence is the killing of virtually all aquatic life in the rivers and severe impacts on Macquarie Harbour. In 2010, the federal government said that the Mt Lyell mine remediation project was not viable - and redirected its $\$ 7$ million contribution to the project to the state's Fox Eradication Program (ABC News 2010c). In both cases, the long-term problems remain.

Waste that accumulates and/or that is transformed into a hazard over time is a major looming problem in Australia. This includes materials from mine tailings through to tyres. The issue of stockpiling - especially of things such as the huge tyres used on mining trucks - is particularly pertinent when considering legacy waste produced by the mining sector. Compounding the problem of future legacy waste and present day stockpiling is the issue of the geographical size of some states (such as Western Australia and Queensland) and the remoteness of potential dumping sites. Assessment, monitoring and intervention in regards to existing and possible hazards have obvious human resource implications, not to mention political, social and economic ramifications (White and Heckenberg 2012). When it comes to horizon issues more generally, it is necessary to give consideration not only to the volatility of industrial stockpiles (for example, chemicals, tailings) but also to their mobility - can they ooze, dissipate, be diluted, seep into a water table, or traverse jurisdictional borders? Under what circumstances might toxic harms move (for example, the flow of chemicals and heavy metals from industrial zones into local waterways such as occurred in Brisbane during flooding) or gain mobility in the event of co-occurring natural and technological disasters (like Fukushima)? 
From the point of view of environmental justice, there are several interconnected issues that need to be addressed at a concrete level. These include:

- the application of the precautionary principle in cases pertaining to the employment of potentially devastating methods and operations (for example, fracking) and those that substantially increase greenhouse gas emissions (for example, open cut mining);

- robust regulation and monitoring of environmental performance, including use of the 'big stick' where required, in order to ensure diminished possibility of contamination and pollution; and

- systematic documentation of environmental victimisation that includes sociological analysis of vulnerable population groups and the impacts of mining company decisions and practices on their livelihoods, health and wellbeing.

All of these, in turn, revolve around the politics surrounding the mining industry generally. Examples of destructive practice can be marshalled relatively easily (as indicated above) but so, too, can examples of efforts by the mining industry to be sensitive to environmental concerns and to the needs and contributions of Indigenous people (see, for example, Lloyd et al. 2002). Active dialogue between stakeholders is advised (Brereton and Forbes 2004) but the success or otherwise of such dialogue will depend in part upon perceptions and practices related to industry regulation.

\section{Questions about regulation}

There is no doubting the national and regional economic importance of the natural resource and extractive industries. But mining of oil, gas and minerals in particular generates considerable hazardous materials and contaminants. Yet, due to issues such as remoteness, political largess and the trend toward self regulation (in some industries), questions can be asked about how adequate the regulation of potential harms and hazards is in relation to the big economic players. For instance, more concrete data is needed in regards to the extent of mining-related contamination in rural and remote areas, in cities and towns, on private and public lands, and in waterways. The damage is being done; we need to know to what extent and how far reaching it is. What we know so far is certainly not encouraging (Munro 2012). Environmental justice also demands that workers, residents and key stakeholders be included as participants in data collection processes, and that their specific vulnerabilities as victims or potential victims of environmental harm be prioritised for analysis and action.

Large corporations have considerable economic and political leverage and this has translated into a light regulatory touch in relation to potential breaches of legislation (Cleary 2012). Recent research on the policing of hazardous waste disposal in Australia, for example, found that regulators have, in some instances, been told to 'back off certain companies by government ministers when particular corporate (and state economic) interests were at stake (White and Heckenberg 2012).

Moreover, regulation has tended to be framed in terms of free market ideology (especially of labour markets) and self-regulation (in terms of operational practices), which have reduced levels of direct state intervention in industries such as mining (Carrington et al. 2011). Yet, systematic review of empirical evidence concerning environmental monitoring and enforcement finds that traditional regulatory structures are most effective in ensuring good environmental outcomes (Gray and Shimshack 2011). The emphasis on de-regulation and selfregulation, however, has tended to further compromise the work of regulatory bodies such as Environmental Protection Agencies which in many cases are already struggling with implementation of out-dated risk-based models (Krpan 2011). A recent review of EPA practices in Victoria recommended a more proactive regulatory model in which the severity of the EPA's enforcement response should be proportionate to any environmental harm or potential harm, 
and the nature and characteristics of the perpetrators likewise taken into account (EPA Victoria 2011; Krpan 2011). Contrary to the general trend, this would require an increase in the level of enforcement and prosecutions, and a substantial increase in the number of authorised officers. Jurisdictions such as Western Australia, Queensland and New South Wales - the heartlands of the mining industry - are unlikely, however, to adopt this more robust regulatory approach, and especially not in relation to this particular industry.

Furthermore, as mentioned above, much of the exploitation of natural resources takes place outside metropolitan areas. If Environmental Protection Agencies and other relevant enforcement bodies do not have adequate staff and material resources, then this will affect when, where, how often and under what circumstances, the policing of mining activities will occur (see White and Heckenberg 2012). The lack of systematic, rigorous and deterrent forms of regulation as applied to resource companied has been noted by Carrington et al. (2011), who observe that, in 2007, the then Western Australian Resources Minister called on mining companies to 'clean up their act' after revealing that 82 per cent of exploration sites inspected in that state, involving 33 different companies, were found to have breached mining regulations (Carrington et al. 2011: 344-345). Repeat offending and recidivist companies are not uncommon, in part due to the sheer distances involved for regulators and the isolation of mining operations.

Compounding the difficulties of regulation and environmental law enforcement in relation to large corporations is the economic co-dependency that may exist between toxic generators and communities. Such communities are more tolerant where they rely on industry for direct employment. This, too, can affect regulatory posture and engagement in such situations. Environmental injustice thus sometimes occurs with the implicit consent of those most likely to be negatively affected in terms of health and wellbeing. Denial of harm can translate into 'not seeing' what is right in front of one's eyes because of assumed benefits from the industry (Natali 2010 ) or due to (mis)understandings of the nature of the harm based upon religious belief (Waldman 2007). The struggle for social and ecological justice is invariably complicated when ideological and philosophical differences among the victims undermine potentially critical reaction to what are objectively destructive environmental practices.

Related to industry development is the notion of shifting the goalposts in order to accommodate local processes. This can sometimes involve moving contamination thresholds up or down to suit local circumstances (White and Heckenberg 2012; see also Cleary 2012). A recent study of environmental law enforcement regulators, for example, exemplifies what can occur. A regulator is quoted as saying:

One of the things that's happened as a result of that activity, is that we allow the management of contaminated soils differently in that area than we would in the rest of the state so there's a notifiable chemical order for mine tailings, arsenic mine tailings, that says that you can reuse arsenic contaminated sand in a variety of ways, at arsenic contamination levels much higher than you would be able to do in the rest of the state. And they've done a whole lot of toxicity and bio availability testing and a number of things to make the case for these higher levels. So it's one of those cases where something in the region has happened historically, and now there's a whole different management regime around reuse of soils, and even landfill has different acceptance of categories for contaminated soils than any other landfills in the state. (White and Heckenberg, 2012: 17)

Dealing adequately with a transgression when it occurs is also difficult under existing systems of regulation and compliance. The penalty imposed should be proportionate to the harm caused and also to the size of the company 'corporate purse', sufficient to represent a significant deterrent rather than a slap on the wrist. This rarely happens in practice. This is especially so 
given the relatively low range for fines relative to the fact that the companies involved 'count their profits in anything from tens of millions to the billions' (Carrington et al. 2011: 345).

Ideally, when it comes to mining and potential environmental harm, there should be wide scale community involvement in risk assessment processes and in after-the-fact diagnosis of alleged harms. If evaluation of toxicity, pollution and contamination is to be free from corrupt processes, then a wide range of stakeholder interests and views needs to be incorporated into the investigation of alleged harms. From a positive affirming perspective, for example, research has demonstrated that participation is important not only from the point of view of the legitimacy of environmental decision-making but that it also can enhance problem-solving (Scott 2005a, 2005b; Steele 2001). If sustainability is the goal, if precaution requires thinking about multiple courses of action, and if community involvement is to be of benefit, then it is clear that citizens ought to be engaged as deliberators and contributors in their own right (White 2012).

However, when environmental harm is contested - conceptually and evidentially - and there are major specific social interests at play (governments, companies, workers, consumers, environmentalists, residents), then those with the power to do so tend to shape public debate in ways that diminish participation and deliberation (see Cleary 2012; Munro 2012). Moreover, it is rare that scientific evidence is uncontested and that proof of environmental harm is simply a matter of 'let the facts decide'. For example, what counts as 'science', what counts as 'evidence', who counts as being a 'scientific expert', and what counts as 'sensible' public policy are all influenced by factors such as economic situation, the scientific tradition within a particular national context, the scientific standards that are used in relation to specific issues, and the style and mode of government (White 2008). This pertains to disputes over mining and contamination of communities as it does to other environmental conflicts.

\section{Conclusion}

This article has explored the social and ecological impacts of mining from the point of view of environmental justice. The concern has been to illustrate the ways in which mining operations and practices variously impinge upon the health and wellbeing of particular population groups - traditional and Indigenous people, children, and local communities situated near mining operations - as well as causing more generalised harms through contributing to global warming.

Air, land and water are directly affected by the extraction (mining) and processing (smelting) of mined substances. So, too, the world's climate is being altered by the emission of greenhouse gases to which mining is a major contributor. Recent developments such as mega-mines and coal-seam fracking will exacerbate these harms due to the scale and nature of the methods used.

In the light of the demonstrated harms from certain mining practices, big questions can be asked about the response from industry and government. The evidence so far is that what is currently in place is woefully inadequate to the task of either taking precaution or rectifying the harm that does occur, even where mining corporations have instituted explicit environmental management and rehabilitation schemes (Cleary 2012; Munro 2012). The track record, both in Australia and globally, suggests that if environmental justice is to be attained in relation to the mining industry, then community vigilance and action is vital - and urgent.

But what kind of action, specifically and concretely, can or should be undertaken in regards to these issues? In part this will be determined by particular local contexts, involving particular communities, particular companies, and particular extractive processes. The relationship between corporations and communities will be influenced by specific economic and political contingencies, including the nature of regulatory structures and approaches, the ebbs and flows 
of community composition and participation, and local cultures and attitudes (of resistance and of collaboration). In some instances, community opposition is more than warranted given the real and perceived costs of mining development; in others, there is scope for industry and community to work together in pursuit of a range of social, ecological and economic objectives.

More generally, there is also greater scope to more directly link environmental justice concerns with the notion of 'social license to operate' (SLO). The pursuit of environmental justice can be practically addressed to some degree by critical application of SLO principles. Industry representatives are already sensitive to the importance of obtaining a modicum of social license, through building trust relationships with local communities and integrating this into contemporary business practice (Lacey et al. 2012). Commentators warn that the SLO must be more than a cover for business-as-usual, an imagined strategy of buying community acceptance and/or not be too focussed on risk at the expense of collaboration (Black 2012; Owen and Kemp 2012). They argue that a robust SLO is measureable, takes hard work and demands a willingness to collaborate with stakeholders. Increasing the expectations surrounding social license may well provide avenues for developing relationships that ensure more equitable and sustainable outcomes. This is vital to the project of environmental justice.

Correspondence: Rob White, Professor of Criminology, School of Sociology and Social Work, University of Tasmania, Australia. Email: r.d.white@utas.edu.au.

\section{References}

ABC News (2007) Esperance Port Authority charged over lead contamination. Australian Broadcasting Corporation, 10 August. Available at http://abc.net.au/news/2007-0810/esperance-port-authority-charged-over-lead/636168 (accessed 15 April 2013).

ABC News (2010a) Another town in water contamination scare. Australian Broadcasting Corporation, 21 July. Available at http://www.abc.net.au/news/2010-07-21/another-townin-water-contamination-scare/914136 (accessed 2 April 2013).

ABC News (2010b) Town's drinking water to be trucked in. Australian Broadcasting Corporation, 22 July. Available at http://www.abc.net.au/news/2010-07-21/townsdrinking-water-to-be-trucked-in/914568 (accessed 2 April 2013).

ABC News (2010c) Mt Lyell mine fix not viable. Australian Broadcasting Corporation, 2 March. Available at http://www.abc.net.au/news/stories/2010/03/02/2834019.htm?site=hobart (accessed 2 April 2013).

Australian and New Zealand Minerals and Energy Council (ANZMEC) and Minerals Council of Australia (MCA) (2000) Strategic Framework for Mine Closure. Canberra: ANZMEC and MCA.

Australian Bureau of Statistics (ABS) (2003) Mining and the environment. 1301.0 - Year Book Australia, 2003. Canberra: ABS.

Black L (2012) The very seductive social license to operate - a reality check, Pro Bono Australia, 31 October 31. Available at http://www.probonoaustralia.com.au (accessed 18 December 2012).

Boekhout van Solinge T (2008) Crime, conflicts and ecology in Africa. In Sollund R (ed) Global Harms: Ecological Crime and Speciesism. New York: Nova Science Publishers: 13-34.

Borras S and Franco J (2010) Towards a broader view of the politics of global land grab: Rethinking land issues, reframing resistance. ICAS Working Paper Series No.001. Published jointly by Initiatives in Critical Agrarian Studies, Land Deal Politics Initiative and Transnational Institute. 
Brereton D and Forbes P (2004) Monitoring the Impact of Mining on Local Communities: A Hunter Valley Case Study. Brisbane: Centre for Social Responsibility in Mining.

Brockmann M (2006) Australia: Mt Isa lead risk for children. The Australian, 21 June.

Brook D (2000) Environmental genocide: Native Americans and toxic waste. American Journal of Economics and Sociology 57(1): 105-113.

Bullard R (1994) Unequal Protection: Environmental Justice and Communities of Color. San Francisco: Sierra Club Books.

Bullard R (2005a) Introduction. In Bullard R (ed) The Quest for Environmental Justice: Human Rights and the Politics of Pollution. San Francisco: Sierra Club Books: 1-15.

Bullard R (2005b) Environmental justice in the twenty-first century. In Bullard R (ed) The Quest for Environmental Justice: Human Rights and the Politics of Pollution. San Francisco: Sierra Club Books: 19-42.

Carrington K, Hogg R and McIntosh A (2011) The resource boom's underbelly: Criminological impact of mining development. Australian and New Zealand Journal of Criminology 44(3): 335-354.

Carrington K, McIntosh A and Scott J (2010) Globalisation, frontier masculinities and violence: Booze, blokes and brawls. British Journal of Criminology 50(3): 393-413.

Chunn D, Boyd S and Menzies R (2002) 'We all live in Bhopal': Criminology discovers environmental crime. In Boyd S, Chunn D and Menzies R (eds) Toxic Criminology: Environment, Law and the State in Canada. Halifax: Fernwood Publishing: 7-24.

Clark B (2002) The indigenous environmental movement in the United States. Organization and Environment 15(4): 410-442.

Cleary P (2012) Mine-Field: The Dark Side of Australia's Resources Rush. Collingwood: Black Inc.

Department of Foreign Affairs and Trade (2008) About Australia: Resources Sector. Australian Government Fact Sheet, last updated January 2008.

Engel S and Martin B (2006) Union Carbide and James Hardie: Lessons in politics and power. Global Society 20(4): 475-490.

Environmental Protection Authority (EPA) Victoria (2011) Compliance and Enforcement Review: Overview of Key Themes and Recommendations for EPA Victoria. Melbourne: EPA Victoria.

Fowler A (2010) A dirty business. ABC Four Corners, 12 April. Australian Broadcasting Corporation. Available at http://www.abc.net.au/4corners/content/2010/s2867659.htm (accessed 2 April 2013).

Friedrichs D and Friedrichs J (2002) The World Bank and crimes of globalization: A case study. Social Justice 29(1-2): 13-36.

Gedicks A (2005) Resource wars against native peoples. In R. Bullard (ed) The Quest for Environmental Justice: Human Rights and the Politics of Pollution. San Francisco: Sierra Club Books:168-187.

Goldman M (1998a) Introduction: The political resurgence of the commons. In Goldman M (ed) Privatizing Nature: Political Struggles for the Global Commons. London: Pluto Press in association with Transnational Institute: 1-19.

Goldman M. (1998b) Inventing the commons: Theories and practices of the commons professional. In Goldman M (ed) Privatizing Nature: Political Struggles for the Global Commons. London: Pluto Press in association with Transnational Institute: 20-53.

Gray W and Shimshack J (2011) The effectiveness of environmental monitoring and enforcement: A review of the empirical evidence. Review of Environmental Economics and Policy 5(1): 3-24. 
Harrison R (2010) How does Rosebery compare with other Australian mining towns? LEAD Action News 11(2): 15-20.

Kirsch S (2006) Reverse Anthropology: Indigenous Analysis of Social and Environmental Relations in New Guinea. Palo Alto, California: Stanford University Press.

Klare M (2001) Resource Wars: The New Landscape of Global Conflict. New York: Owl Books, Henry Holt and Company.

Klare M (2012) The Race For What's Left: The Global Scramble for the World's Last Resources. New York: Metropolitan Books, Henry Holt and Company.

Krpan S (2011) Compliance and Enforcement Review: A Review of EPA Victoria's Approach. Melbourne: EPA Victoria.

Lacey J, Parsons R and Moffat K (2012) Exploring the Concept of a Social License to Operate in the Australian Minerals Industry: Results from Interviews with Industry Representatives. EP125553. Brisbane: CSIRO.

Lloyd M, Barnett G, Doherty M, Jeffree R, John J, Majer J, Osborne J and Nichols 0 (2002) Managing the Impacts of the Australian Minerals Industry on Biodiversity. Brisbane: Australian Centre for Mining Environmental Research.

Low N and Gleeson B (1998) Justice, Society and Nature: An Exploration of Political Ecology. London: Routledge.

Martin S and Newell K (2008) Mining Ombudsman Case Report: Rapu Rapu Polymetallic Mine. Carlton: Oxfam Australia.

Millner F and Ruddock K (2011) Climate litigation: Lessons learned and future opportunities. Alternative Law Journal 36(1): 27-32.

Mudd G (2008) Environmental regulation of uranium mining on Indigenous land surrounded by a world heritage-listed national park: A brief review of the Ranger Uranium Project. National Environmental Law Review 2: 36-42.

Muirden A and Parnell M 2003 A Very Dirty Story: Protecting the Whyalla Community from Red Dust Pollution Caused by the OneSteel Pellet Plant. Adelaide: Environmental Defenders Office.

Munro S (2012) Rich Land, Wasteland - How Coal is Killing Australia. Sydney: Pan Macmillan Australia.

Natali L (2010) The big grey elephants in the backyard of Huelva, Spain. in White R (ed) Global Environmental Harm: Criminological Perspectives. Devon: Willan Publishing: 193-209.

Owen J and Kemp D (2013) Social license and mining: A critical perspective. Resources Policy 28(1): 29-36.

Pellow D (2007) Resisting Global Toxics: Transnational Movements for Environmental Justice. Cambridge: The MIT Press.

Queensland Health (2008) Mount Isa Community Lead Screening Program 2006-7. Online: Environmental Health Services of the Tropical Population Health Network, Northern Area Health Service, Queensland Health. Available at www.heath.qld.gov.au/ph/documents/tphn/mtisa_leadrpt.pdf (accessed 15 April 2013).

Rush S (2002) Aboriginal Resistance to the Abuse of Their National Resources: The Struggles for Trees and Water. In Boyd S, Chunn D and Menzies R (eds) Toxic Criminology: Environment, Law and the State in Canada. Halifax: Fernwood Publishing: 67-86.

Saha R and Mohai P (2005) Historical context and hazardous waste facility siting: Understanding temporal patterns in Michigan. Social Problems 52(4): 618-648.

Schlosberg D (2007) Defining Environmental Justice: Theories, Movements, and Nature. Oxford: Oxford University Press. 
Scott D (2005a) When Precaution Points Two Ways: Confronting 'West Nile Fever'. Canadian Journal of Law and Society 20(2): 27-65

Scott D (2005b) Shifting the burden of proof: The precautionary principle and its potential for the 'democratization' of risk. In Law Commission of Canada (eds) Law and Risk. Vancouver: UBC Press: 50-85.

Smandych R and Kueneman R (2010) The Canadian-Alberta tar sands: A case study of statecorporate environmental crime. In White R (ed) Global Environmental Harm: Criminological Perspectives. Devon: Willan Publishing: 87-109.

Steele J (2001) Participation and deliberation in environmental law: Exploring a problemsolving approach. Oxford Journal of Legal Studies 21(3): 415-442.

Thomson I and Boutilier R (2011) Social license to operate. In Darling P (ed) SME Mining Engineering Handbook. Littleton, Colorado: Society for Mining, Metallurgy and Exploration: 1770-1796.

Thomson I and Joyce S (2006) Changing mineral exploration industry approaches to sustainability. In Doggett M and Parry J (eds) Wealth Creation in the Minerals Industry: Integrating Science, Business and Education. Littleton, Colorado: Society of Economic Geologists: 149-170.

Townsend I (2013) Queensland's toxic Dee River reveals national mine waste problem. Background Briefing, 14 February. ABC Radio National. Available at http://www.abc.net.au/radionational/programs/backgroundbriefing/toxic-minewater/45... (accessed 1 March 2013).

United States House of Representatives Committee on Energy and Commerce Minority Staff (2011) Chemicals Used in Hydraulic Fracturing. Washington, DC: US House of Representatives.

Waldman L (2007) When social movements bypass the poor: Asbestos pollution, international litigation and Griqua cultural identity. Journal of Southern African Studies 33(3): 577-600.

White R (2008) Crimes Against Nature: Environmental Criminology and Ecological Justice. Devon: Willan Publishing.

White R (2011) Transnational Environmental Crime: Toward an Eco-Global Criminology. London: Routledge.

White R (2012) Environmental forensic studies and toxic towns. Current Issues in Criminal Justice 24(1): 107-122.

White R (2013) Harm: An Eco-Justice Perspective. Bristol: Policy Press.

White R and Heckenberg D (2012) Policing Hazardous Waste Disposal Project: Key Trends and Issues,Briefing Paper \#7. Hobart: Criminology Research Unit, University of Tasmania.

Williams C (1996) An environmental victimology. Social Justice 23(4): 16-40. 